\title{
Neem and its Derivatives- A Tropical Trove
}

\author{
Nidhi Mehta*, Anup Chandra and Ajay Thakur
}

Forest Genetics \& Tree Improvement division, Forest Research Institute, Dehradun, India

*Corresponding author

A B S T R A C T

\begin{tabular}{l} 
Ke y w o r d s \\
Azadirachta indica, \\
Derivatives, \\
Therapeutic, \\
Applications, Indian \\
\hline Article Info \\
\hline $\begin{array}{l}\text { Accepted: } \\
\text { 22 January } 2021 \\
\text { Available Online: } \\
\text { 10 February } 2021\end{array}$ \\
\hline
\end{tabular}

\section{Introduction}

Meliaceae is also known as Mahogany family. It is a huge family containing $49-50$ genera and 620 species, spread in pan-tropical area escalating to temperate zone. In India it amounts to 20 genera and 70 species (Mabberley et al., 2007). The majority of the members of the family are shrubs and big trees such as Cedrela toona, Chloroxylon, Azadirachta indica, Swietenia mahogani, Carapaobovata etc. Various members of the family are extensively used for timber, fruits, shade and medicinal values. A large number of biologically active compounds have also been identified from family meliaceae (Mabberley et al., 1995). The most important and most researched tree of this family is Neem, Azadirachta indica which also belongs to sub-family Meloideae and tribe Melieae (Thakkar 1997). It is also known as Margosa or Indian lilac, commonly. It is a fast-growing evergreen tree (Pingale 2010). For 4000 or more years, it is being utilized in the ayurvedic medicines owing to its plethora of medicinal properties (Tomar et al., 2011). Acknowledging its importance U.S. National Academy of Sciences has published a report entitled as "Neem- a tree for solving global problems" in 1992 (Yasmin and Sultana 2017). It is also named as "Bitter gem" which means "Karwa Amrit". Ancient documents like Charak-Samhita and Susruta-Samhita also mentioned the advantages of the Neem. 
As it holds the potential in the sector of environment, pest management and medicine due to which it is said to be the foremost promising tree of 21 st century. Diverse parts of plant are valuable in diabetes, leukoderma, leprosy, helminthiasis, ulcers, etc. It plays the key part within Ayurveda which is the establishment of the Indian framework of natural treatment (Sateesh, 1998). Neem is acknowledged as a gift of nature to tackle the global problems related to health, agriculture and environment (Venugopal and Visweswaran, 2013).

\section{Neem: A tropical plant}

\section{Taxonomic position}

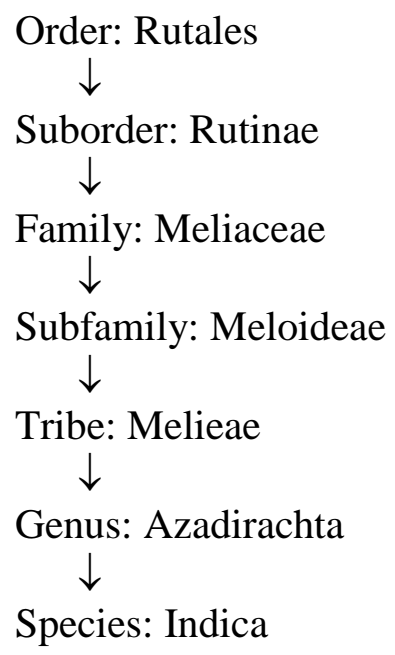

Neem is a robust tree that develops energetically in troublesome locales. There are an assessed 25 million trees or above present in all over India. Tamilnadu placed in the first position, followed by Uttar Pradesh which is followed by Karnataka on third position in overall growing of neem tree in India (Tomar et al., 2011). Neem is a huge tree developing around $25 \mathrm{~m}$ in tallness with semi-straight to straight trunk, $3 \mathrm{~m}$ in circumference and spreading branches shaping a wide canopy. In around 10 years it gets to be completely productive (Raj and Toppo, 2015).The plant is detailed to live up to two centuries (Yasmin and Sultana, 2017). The tree has flexibility to adapt a wide extend of climatic, topographic and edaphic components (Girish and Shankara, 2008).

Distribution: It is far and wide found from higher elevation highlands to lowlands and is one of imperative constituent in tropical and subtropical evergreen forests (Wongprasert et al., 2011).

\section{Botanical description}

Synonym: Antelaea azadirachta

Sanskrit synonym: Pakvakrita, nimbaka

Regional names

English: Indian lilac

Hindi: Neem

Manipuri: Neem

Marathi: Nimbay

Tamil: Veppai, Sengumaru

Malayalam: Ariyaveppu

Telugu: Vepa

Kannada: Turakabevu

Bengali: Neem

Urdu: Neem

Assamese:Neem

Gujarati: Dhanujhada, Limba

The bark is fissured or textured, and whitishgrey to reddish-brown. The leaves are alternate and pinnate. The blooms (white and fragrant) are organized axillary, ordinarily more-or-fewer hanging panicles. The fruit is usually glabrous drupe which is olive-like and shifts in shape from elongate oval to roughly roundish as shown in Figure 1 (Wordpress, 2018).

\section{Traditional and scientific applications}

Nearly each portion of the tree is finds therapeutic utilize, so much so that the bitter taste of the tree is world renowned and it is still accepted that the more bitter, the way better. Neem is well-known for its tough 
wood. Also, various non-wood products are used such as seeds are used for yielding oil and cake. Neem oil is especially used in various roles such as analgesic, anticholinergic, antihelminthic, antihistaminic, antiprotozoal, antipyretic, antiviral, bactericidal, contraceptives, fungicides, insecticides, insect repellents, veterinary medicines, cosmetics, hairoils, lubricants, propellants, shampoos, soaps, toothpaste (Natrajan et al., 2002). Neem cakes are mainly used in animal feed, soil fertilizer, soil moisturizer, soil neutralizer, soil protectant. Leaves are utilized for antidermatic, antifungal, anticlotting agent, antihelminthic, antituberculosis, anti tumour, antiseptic, antiviral, contraceptive, cosmetics, fertilizers, insecticides, nematicides, insect repellents. Twigs for oral deodorant, toothache reliever, tooth cleaners. Bark in antiallergenic, antidermatic, antifungal, antiprotozoal, antitumor, deodorant. Flowers are a basic component of analgesic, curries, nectaries, soaps, stimulant (Jattan et al., 1995). Neem derivatives are also used for mosquito repellent, fumigation concerning hygiene by burning leaves and bark, for the treatment of viral infections such as small pox, chicken pox etc. (Anonymous 2006). Also, a main component of dental hygiene as it reduces the bacterial count and oral plaque index (Chaurasia, 2016).

Various biological active compounds were also extracted from the neem tree and its different parts which are known to be biologically active. Over 135 biological active compounds have been isolated from the diverse parts of neem. Bioactivities of only limited compounds have been examined. These extracted biological active compounds are namely, Nimbidin, Sodium nimbidate, Nimbin, Nimbolide, Gedunin, Azadirachtin, Mahmoodin, NB-II peptidoglycan, Polysaccharides, Polysaccharides GIIa, GIIIa, Polysaccharides GIa, Gib, Cyclic trisulphide and cyclic tetrasulphide, Margolone, margolonone and isomargolonone, Gallic acid, (-) epicatechin and catechin, Margolone, margolonone and isomargolonone showing various effects such asanti-inflammatory, Antiarthritic, Antipyretic, Hypoglycaemic, Antigastric ulcer, Spermicidal, Antifungal, Antibacterial, Diuretic, immunomodulatory, Antimalarial as shown in Figure 2 (Hail et al., 2020). Neem is also extensively used for other variants viz. adhesives, food from fruits, fuel wood, glue, honey, pulp biogas, resin, tannin, windbreaker, wood preservatives (Biswas et al., 2002).

\section{Neem in agriculture:}

Taking into consideration the havoc caused by the synthetic chemicals or pesticides used in modern agriculture has instigated the need to use the neem derivatives in the agriculture sector. To lower the risk, these derivatives can be used in various roles such as organic manure, fertilizer, for pest control or management and fumigants etc. Neem as a manure has shown an impressive omnipresence, because it is eco-friendly and collectively all the compounds found in it offer assistance to increase the nitrogen and phosphorous percentage within the soil. It is wealthy source of sulfur, potassium, calcium, nitrogen, etc.

This property makes neem an excellent biofertilizer which makes a difference by giving the desired supplements to the plants and deficient lands (Joseph et al., 2010). Subsequently, which acts as enricher of the soil decreases the development of bacteria and pest in the soil (Murthy and Sirsi, 1958). Also, it supplements with the macronutrients fundamental for the plant development, and efficient in maximizing the plants yield in future (Pant et al., 1986). Owing to the above said positive effect in the soil it also plays a brilliant role as an organic soil conditioner 
which improves the soil health and eventually leads to better growth of plants and increase in yield. As neem has azadirachtin an active ingredient, it protects the plant from the attack of pathogens and insect pest. Presently, ready for use neem based urea-coating agents which aims to impede the growth and activity of the bacteria involved in denitrification process are commercially accessible in India viz. "Nimin". Also this is available in liquid and powdered form, both (Jagannathan et al., 2014).

Many formulations are commercially available such as Bioneem, Neemark etc which provides utmost protection against pathogenic fungus owing to its antifungal properties. Providing the environment friendly and cheap option which is not recalcitrant in nature and also, does not add to any contamination to land or aquatic resources but adding to the soil fertility (Bhonde et al., 1999).

\section{Neem and sustainable environment}

Neem as tree has a great importance in agroforestry and shows a very high potential for sustainable environment. It helps globally to combat the issues of deforestation, soil erosion, and global warming etc (Nigam et al., 1994).

It helps in planting more oxygen world wide as it has high rate of photosynthesis and also maintains low temperature (approx. $10^{\circ} \mathrm{C}$ ) beneath the canopy which resolves the issue of increasing global warming and natural cooler in the hottest month of the year. Neem can be used for shade, wind breaks due to its huge canopy, and firewood because of high calorific value, shelter as the wood is termite resistant and robust (Randhawa and Parmar 1993). Neem leaf powder is also used as biosorbent owing to its water purifying property which helps in removing dyes from the water such as Congo red (Bhattacharyya and Sharma, 2004).

Fig.1 Neem and its products
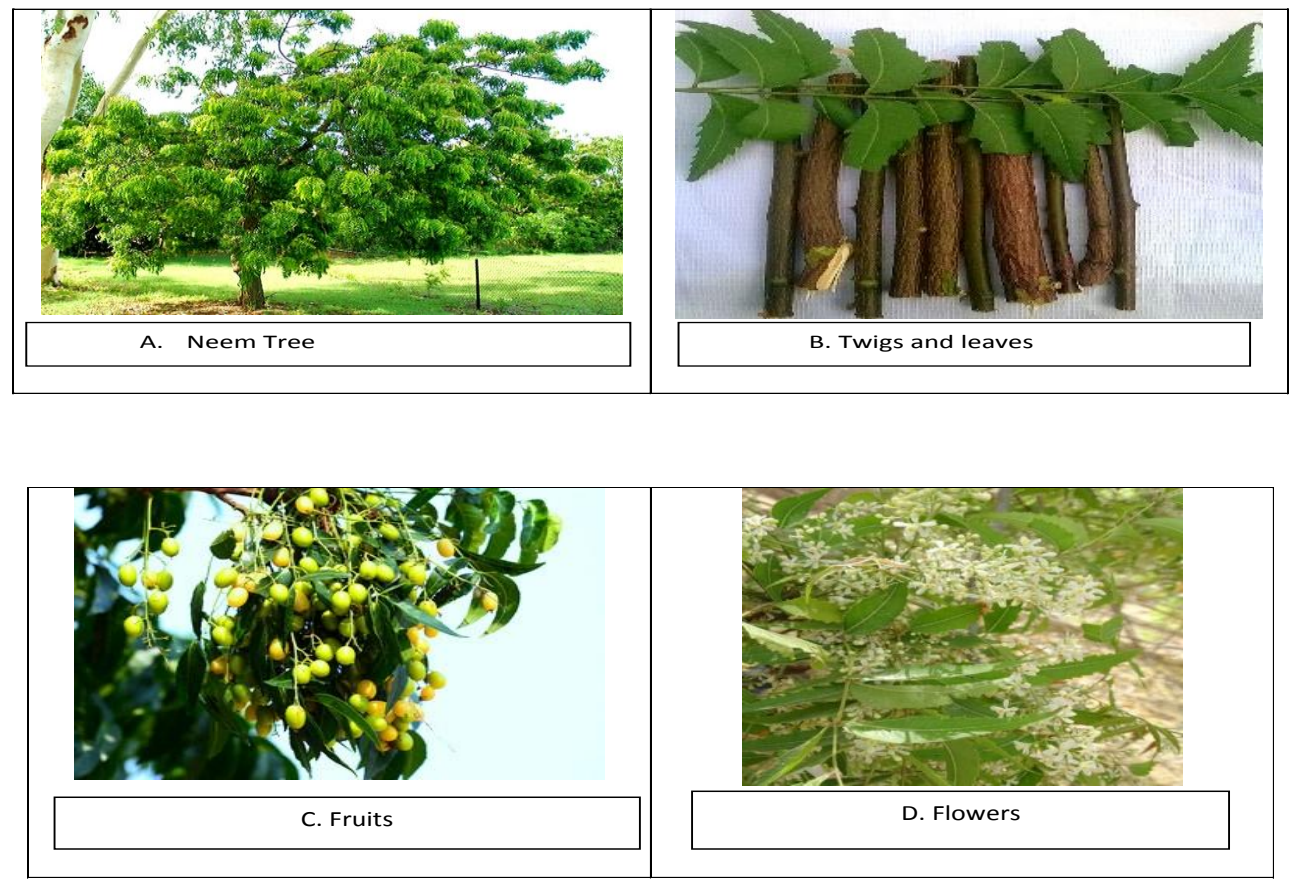
Fig.2 Some biologically active compounds isolated from Neem

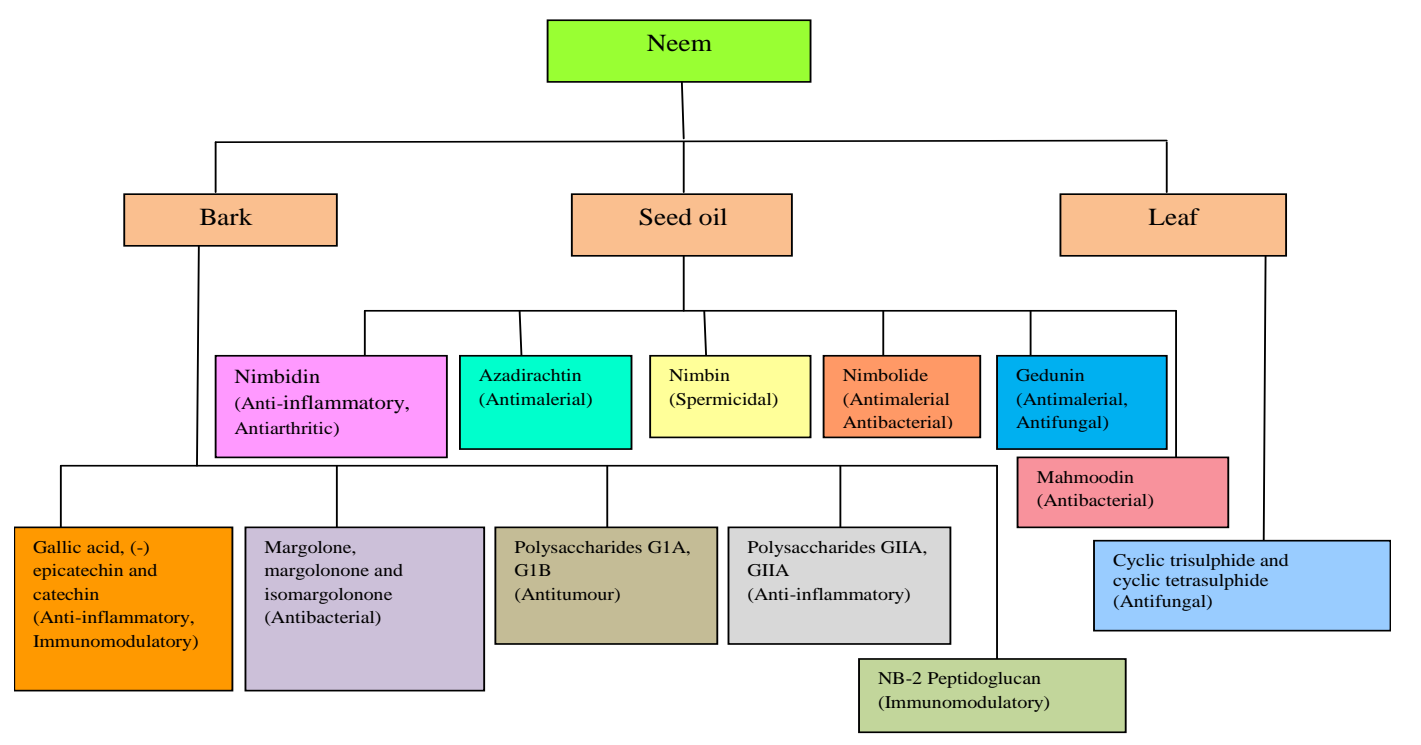

\section{Industrial applications}

Neem acts as a promising industrial plant as its derivative or the whole plant is extensively exploited in various industries such as pharmaceuticals, agro-biochemical, cosmetics, textile, tanning, food, and livestock feed and supplies etc. It is highly used as the main components in shampoos, toothpaste, face creams, nail oils and soaps against head lice, bacterial and fungal infections. Neem is also being used extensively as nutraceuticals due to its antiviral, antibacterial, antifungal and immunomodulatory properties (Khanna, 1992). They also play their role as biorodenticides and bio-pesticides. Neem pulp is utilized in the fermentation and methane production industry as it is a rich source of carbohydrate. Gum, bark, leaves, fruits and seeds provide a huge variety in livestock feeds which consequently helps in keeping up the animal health.

Neem oil and leaves are inseparable part of animal feed as it is a good source of minerals, proteins and carotene. Neem leaves are also used as a part of poultry feed to keep the aflatoxicosis caused by Aspergillus flavus away, which is a major threat to poultry industry (Allameh et al., 2002).

Neem has become an intricate part of large scale as well as small scale industries, latter holding much more potential. Also, including the women self help groups which are dependent on neem and its derivative, to large extent. In the industry sector, annual estimated turnover of azadirachtin is approx. Rs. 1000-1200 crores. This gives a great insight to promote the industries with the help utilizing neem and its derivatives in the coming future (Kumar, 2003).

\section{Therapeutic uses}

Since ages, neem has been seen to provide magnificent health encouraging properties. It has been a firm part of all form of medical practices such as Homopathic, Ayurvedic, Unani and Allopathy. Using various parts of neem different diseases are cured related to dentistry, metabolism, skin, hair, heart and kidney related problems as they show various pharmacological activities such as antiinflamatory, anti-bacterial, anti-viral and antifungal (Subapriya and Nagini, 2005). 
The bark is documented to show positive effects in treating vomiting, cough and skin diseases. Neem oil is reported to show pain relieving property subsequently leading to wound healing action (Kumar et al., 2012). Pharmacological hypoglycemic action of neem has also been shown to help in diabetes (Dholi et al., 2011). Neem also curb the growth of malignant cancer due to some flavanoids and other components present in it, which makes it a great candidate to be assessed in the studies of anti-cancerous agents (Rahmani et al., 2014). It also shows efficient role as antifungal against the activity of Aspergillus and Rhizopus. It also has great impact in skin appearance and lowering down of body temperature owing to its cooling property. As neem has sedative effects, it is also used as stress reliever. It has a potential role in contraceptives as well because it animates the cell and macrophages due to its immune modulant property, it terminates the pregnancy (Giri et al., 2019). Leaf, flower, seeds and bark of neem also helps in the neutralizing the free radicals and plays a very important role as anti-oxidants (Ghimeray et al., 2009).

\section{Safety}

Neem and its derivatives are widely used around the globe and hence seem to be quite safe and sound (Kale and Tayade, 2003). It has shown no side effects on animals or humans throughout its usage till date. Neem oil is still continued to be the bone of contention. Although it is natural antioxidant but still in rare cases, complications like vomiting, diarrhea, jaundice along with hypoglycemia are witnessed, if it is consumed in high concentrations (Kumar et al., 2016).

In conclusion the recent years, the organic or plant-based market is very much in demand. Also, it is safe and efficient to use such products without thinking much about the repercussions. Concluding to which, neem is the immense source of therapeutic and prophylactic potential which needs to be harnessed in the coming future to make our earth a better place to inhabit.

\section{References}

Abhishek Raj and Pratap Toppo. 2015. Beneficial and Harmful Effects of Azadirachta Indica: A Review. Volume 4. Issue 3.

Akhilanand Chaurasia. 2016. Neem in Oral Diseases - An Update. Journal of Oral Medicine, Oral Surgery, Oral Pathology and Oral Radiology 2(1):1-3.

Allameh, A., Razzaghi, A.M., Shams, M., et al., 2002. Effects of neem leaf extract on production of aflatoxins and activities of fatty acid synthetase, isocitrate dehydrogenase and glutathione S- transferase in Aspergillus parasiticus. Mycopathologia 54: 79-84.

Anis Joseph, R., Premila, K.S., Nisha, V.G., Soorya Rajendran and Sarika Mohan, S. 2010. Safety of neem products to tetragnathid spiders in rice ecosystem. Journal of Biopesticides, 3(1): 88-89.

Anonymous.2006. Neem - Growing neem, organic farming, health, animal health, environmental use, home uses, economic potential, patent bazaars, research papers, world neem conference. Neem foundation Internet Mumbai, India - [cited 2006 Jun 20]. Available from: http://www.neemfoundation.org/.

Bhattacharyya, K.G., Sharma, A. 2004 Azadirachta indica leaf powder as an effective biosorbent for dyes: a case study with aqueous Congo red solutions. J Environ Manage. 71: 217229.

Bhonde, S.B., Deshpande, S.G., Sharma, R.N., 1999 In vitro evaluation on 
inhibitory nature of some neem formulations against plant pathogenic fungi. Hindustan Antibiot Bull, 41: 2224.

Biswas, K., Chattopadhyay, I., Banerjee, R.K., et al. 2002 Biological activities and medicinal properties of neem Azadirachta indica. Curr Sci. 82: 13361345.

Dr.R.Jagannathan et al. 2014. A review on neem derivatives and their agricultural applications. International Journal Of Pharmacy \& Technology. Vol. 6. Issue No.3. 3010-3016.

Geremew Haile et al. 2020 Review on Medicinal Value and other Application of Neem Tree: Senior Seminar on Animal Health. ARC Journal of Immunology and Vaccines Volume 2, Issue 2, PP 16-24.

Ghimeray, A. K., C. W. Jin, B. K. Ghimire, and D. H. Cho. 2009. "Antioxidant activity and quantitative estimation of azadirachtin and nimbin in Azadirachta indica A. Juss grown in foothills of Nepal," African Journal of Biotechnology, vol. 8, no. 13, pp. 3084 3091.

Jattan, S.S., Shashikumar, Pujar, G., et al., 1995 Perspectives in intensive management of neem plantations. Indian For. 121: 981-988.

Kale, B.P., Kothekar, M.A., Tayade, H.P., et al., 2003. Effect of aqueous extract of Azadirachta indica leaves on hepatotoxicity induced by antitubercular drugs in rats. Ind. J. Pharmacol. 35. $177-180$.

Khanna, A. 1992 Neem gains honour as India's wonder tree. Down to earth 1: 511

Kumar, A.R.V., 2003 Neem for the industry or for the common man: where does India stand? Curr Sci, 84: 265-267.

Kumar, D., Rahal, A., and Malik, J. K. 2016. Neem Extract. Nutraceuticals, 585-597. doi:10.1016/b978-0-12-802147-

7.00043-7.

Mabberley, D. J., Pannell, C. M., Sing, A. M. 1995. Flora Malesiana: Series I. Spermatophyta Volume 12, part 1, 1995. Meliaceae. 407 pp.

Mabberley, D.J., Pannell, C.M., Edmonds J.M. and Sing, A.M. (2007). Meliaceae. In: E. Soepadmo, L.G. Saw \& R.C.K. Chung (eds), Tree Flora of Sabah and Sarawak 6: 17-218. Forest Resarch Institue. Malaysia, Kepong.

Murthy, S.P. and Sirsi, m. 1958. Pharmacological studies on Melia Azadirachta indica. Indian Journal of Physiology and Pharmacology 2, 387396.

Nigam, S.K., Mishra, G., Sharma, A.. 1994 Neem: A promising natural insecticide. Appl Bot Abstr. 14: 35- 46.

Pant, N., Garg, H. S., Madhusudanan, K. P. and Bhakuni, D. S., Fitoterapia, 1986, Sulfurous compounds from Azadirachta indica leaves, 57, 302-304

Pingale Shirish S. 2010. Hepatoprotection study of leaves powder of Azadirachta indica A. juss. International Journal of Pharmaceutical Sciences Review and Research. Volume 3. Issue 2. 37-42.

Rahmani A.H., M. A. Alzohairy, M. A. Khan, and S. M. Aly. 2014. "Therapeutic implications of black seed and its constituent thymoquinone in the prevention of cancer through inactivation and activation of molecular pathways," Evidence-Based Complementary and Alternative Medicine, vol. 2014, Article ID 724658, 13 pages.

Randhawa, N.S., Parmar, B.S. 1993 Neem: Research and development. Society of Pesticide Science. IARI. New Delhi. India.

Rudra Prasad Giri et al. 2019. Neem the Wonder Herb: A Short Review. International Journal of Trend in 
Scientific Research and Development. Volume-3. Issue-3. pp.962-967.

S. K. Dholi, R. Raparla, S. K. Mankala and K. Nagappan, 2011. "In vivo antidiabetic evaluation of Neem leaf extract in alloxan induced rats," Journal of Applied Pharmaceutical Science, vol. 1, no. 4, pp. 100-105.

S. Kumar, D. Agrawal, J. Patnaik, and S. Patnaik, 2012. "Analgesic effect of neem (Azadirachta indica) seed oil on albino rats," International Journal of Pharma and Bio Sciences, vol. 3, no. 2, pp. P222-P225.

Sabina Yasmin, Razia Sultana. 2017. Neem (Azadirachta Indica): A Potential Medicinal Plant. Vol. 6, Issue 10 bazaars, research papers, world neem conference. Neem foundation internet Mumbai, India.

Sateesh, M.K. 1998. Microbiological investigations on die-back disease of neem Azadirachta indica A. Juss.. Ph.D. thesis. University of Mysore. Mysore. India.

Subapriya, R., Nagini, S., 2005 Medicinal properties of neem leaves: a review. Curr Med Chem Anticancer Agents 5: 149-156.

Thakkar, P.S. 1997. Editorial notes. Global Neem Update 2: 1.

Tomar Lokeshwar et al. 2011. On neem (azadirachta indica): thousand problems one solution. IRJP, 2 (12), 97102 Review.

V Natarajan et al. 2002. Antidermatophytic activity of Azardirachta indica (neem) by invitro study. Indian Journal of Pathology and Microbiology 45(3):3113.

Venugopalan Santhosh Kumar and Visweswaran Navaratnam 2013. Neem (Azadirachta indica): prehistory to contemporary medicinal uses to humankind. Jul; 3(7): 505-14.

Wongprasert, T., Phengklai, C. \& Boonthavikoon, T. (2011). A synoptic account of the Meliaceae of Thailand. Thai Forest Bulletin (Botany) 39: 210266.

\section{How to cite this article:}

Nidhi Mehta, Anup Chandra and Ajay Thakur. 2021. Neem and its Derivatives- A Tropical Trove. Int.J.Curr.Microbiol.App.Sci. 10(02): 3228-3235. doi: https://doi.org/10.20546/ijcmas.2021.1002.354 